\title{
Analysing the Public Administration and Decision-Makers Perceptions Regarding the Potential of Rural Tourism Development in the Azores Region
}

\author{
Rui Alexandre Castanho ${ }^{1,2,3,4,5^{*}}$, Gualter Couto ${ }^{1}$, Pedro Pimentel $^{1}$, Célia Carvalho ${ }^{6,7}$, Áurea Sousa ${ }^{8}$, Maria da Graça \\ Batista $^{1}$ \\ ${ }^{1}$ School of Business and Economics, University of Azores and CEEAplA, Ponta Delgada 9500-321, Portugal \\ ${ }^{2}$ Faculty of Applied Sciences, WSB University, Dąbrowa Górnicza 41-300, Poland \\ 3 CITUR - Madeira - Centre for Tourism Research, Development and Innovation, Funchal-Madeira 9000-082, Portugal \\ ${ }^{4}$ VALORIZA - Research Centre for Endogenous Resource Valorization, - Polytechnic Institute of Portalegre (IPP), Portalegre \\ 7300 , Portugal \\ ${ }_{6}^{5}$ Aquageo Ambiente Legal—University of Campinas, Brazil (UNICAMP), Campinas 13083-970, Brazil \\ ${ }^{6}$ Faculty of Social and Human Sciences, University of Azores and CINEICC - Cognitive and Behavioral Centre for Research \\ and Intervention, Ponta Delgada 9500-321, Portugal \\ ${ }^{7}$ Faculty of Psychology and Educational Sciences, University of Coimbra, Coimbra 3000-115, Portugal \\ ${ }^{8}$ Faculty of Sciences and Technology, University of Azores and CEEAplA, Ponta Delgada 9500-321, Portugal
}

Corresponding Author Email: acastanho@wsb.edu.pl

https://doi.org/10.18280/ijsdp.160401

Received: 11 January 2021

Accepted: 6 April 2021

\section{Keywords:}

Azores islands, public administration, regional studies, rural tourism, sustainable planning, sustainable tourism

\begin{abstract}
Considering that tourism is one of the drivers of the development of peripheral territories, it seems essential to understand the main regional actors' opinions and perceptions to design more coherent and successful sustainable development regional plans. In this regard, the present study intends to assess the Public Administration and Decision-Makers perceptions Regarding the Potential of Rural Tourism Development in the Azores. Contextually, through an exploratory methodology, it was possible to assess the Azores Public Administration and Decision-Makers perceptions. Therefore, it was possible to understand that the majority believe that rural tourism has increased in the Azores Region's last decade (90.2\%). Regional development has been positive and has positively impacted the local population (97.6\%). Besides, the decision-makers and public administration assign greater importance to the "Protection and conservation of Nature" and "Greater commitment and political transparency" as the most critical factors for the success of rural tourism in the Region. The study also identifies the main benefits of this type of tourism for local communities: job creation, Strengthening the local economy, countering local desertification, and developing trade, services, and activities. Therefore, the design of future regional plans that aim at sustainable development must definitely consider the factors identified concerning rural tourism.
\end{abstract}

\section{INTRODUCTION}

It is a fact that rural tourism can add to the development of rural areas or low-density areas and their regional sustainable development [1-7]. In this regard, it should be highlighted that these areas have many problems related to economic decline, a large increase in unemployment, emigration, adverse impacts of the restructuring of agriculture, and the loss of cultural identity [8-10]. If we look at a European level, the countries whose preponderance of its regions are less competitive are Southern Europe, where agriculture performs a relevant role. So, Labrianidis et al. [9] argue that entrepreneurship, associated with small and medium-sized businesses, is one way to achieve sustainable development in Southern European countries once it allows increasing the employment and the incoming. The experimental results of a research that discussed the variation of entrepreneurship among regions of different sizes showed that external and local access to the Gross Regional Product (or accessibility to markets) has a significant impact on the entry and exit of new companies [11]. This impact is negative for the primary and secondary sectors, while for the services sector, this impact is positive [11].

Also, employment in tourism has significantly contributed to the national economy's growth and the transformation of some regional economies [12]. The empirical evidence reveals that tourist spending creates more jobs and income than any other sector of the economy and generates and maintains employment in other sectors of the economy that support or provide visitors and tourist companies. Several studies conducted in developing countries and rural areas witness to this argumentation (see: [13-17] are just a few examples).

Furthermore, not all rural areas that lack employment opportunities and income are candidates to boost tourism as a strategy for economic development [14]. The rural areas must have quality resources and know-how to take advantage of them. In such cases, tourism can be one activity capable of contributing to the: (i) revitalization of local economies; (ii) diversification of activities that are tributaries; (iii) development of other economic sectors (by the multiplier 
effect); (iv) creation and qualification of employment; (v) income generation; (vi) improvement of transport infrastructure, of services (which also benefit the local society); and (vii) the creation of local government revenue [18].

Still, a strategy may not succeed everywhere or under all conditions, but in some places, under some conditions. According to Kilkenny \& Partridge [19], this means that: "(...) firstly, a country development policy must be based on large investments at the level of infrastructure and services essential to the investment (roads, railways, electrification, and so on) and the establishment of human resources." So, tourism should be only one component of a broader rural development program, being essential to a close collaboration between the public sector, the private sector, communities, and civil society, in order to ensure that the goals of its investment policy are achieved $[15,20]$.

Contextually, nowadays, sustainable development and growth are unquestionably one of the central concerns and aspirations of regional territories [21]. This growth is no longer just a dream but a territorial need to enhance the populations' quality of life and ensure future generations [22, 23].

Thereby, territorial planning policies are an indispensable instrument for empowering pre-conditions of resources to the inhabitants [24]. In fact, those planning instruments support success for future living in that region, promoting the dissolution of social unbalances and spatial inequalities and being an inspiration tool for sustainable development [21, 23].

Consequently, investigations that intersect and analyze territorial planning, strategic planning, other planning related methods, and their connection with tourism activities are crucial to the sustainable development of these regions. Thus, and based on the characteristics displayed by the isolated and ultra-peripheral territory of the Azores Archipelago, the following research question is established: "What is the perception of Public Administration and Decision-Makers About the Potential of Rural Tourism Development in the Azores Region?".

This article is the first to explore public administration and decision-makers' perceptions about the potential of rural tourism development in the Azores Region from an academic perspective. Once this study goes further than the theoretical sphere by examining the opinions of those in a position to design and implement regional public policies, it is expected that will add to the thematic literature.

Contextually, to solve the research question, we employed testing tools regarding Azores Public Administration and Decision-Makers' perception of the potential of rural tourism development in the Azores region.

\section{RURAL TOURISM AND REGIONAL DEVELOPMENT IN BRIEF}

The United Nations World Tourism Organisation UNWTO [25] defined tourism as "(...) the activities of persons traveling and staying in places outside their usual environment for not more than one consecutive year for leisure, business, and other purposes." Based on this definition, three characteristics should be included: (i) transportation outside; (ii) reason for traveling; and (iii) the maximum number of days stayed [26].

Contextually, tourism development improves tourism facilities or activities to attract visitors, including the sustainability of these activities with the benefit for tourists, community members, and the tourism destination. The resilience of a tourism destination should be advanced [27]

\subsection{Rural tourism and regional development}

Among the several tourism typologies, there are some more connected with rural tourism activity. Therefore, considering this research's scope, agritourism, ecotourism, nature-based tourism, or wine tourism deserve a closer look.

In this regard, agritourism can be defined as an activity, which inspires travelers to visit farms [28]. Different forms of agritourism exist, specifically farm, farm-based and rural tourism [29]. Sonnino [30] defines an agricultural producer's and their family's hospitality actions that link to any form of farming. Barbieri and Mshenga [31] identified agritourism as the operation developed to draw visitors to an operative farm. In some cases, these visitors are from urban areas rather than rural areas in which the farm is located [27]. Most of these individuals farm as substance farming. Here we exclude commercial farming, which is on a wider scale. Examples of agritourism include wine tourism, farmers' markets, or fruit picking, are just some examples.

Ecotourism aims to generate knowledge, generate capital for conservation, improve attention of cultures, and lastly, better regional communities, economic inclusion, and political power [27-29]. This kind of tourism brings tourists to a region that encompasses the fauna, flora, and culture. In this sense, we also have geotourism, a tourism type that means recognizing the physical environment that cultivates conservation through education and other procedures [32]. As examples of geotourism activities, we have geo-trails, protected area visits, or guided tours [27-29].

Wine tourism includes more than only the consumption of wine [27]. In fact, authors as Mitchell and $\mathrm{Li}$ [33] differentiated among primary wine tourism, which is for wine tasting and procurement, and secondary or 'peripheral' wine tourism motivations - i.e., festivals and gastronomy. Also, wine consumption close to the area where the wine was made is identified as wine tourism or enotourism [27, 28].

\subsection{Rural tourism and regional development}

Besides all the already knew benefits of developing tourism in a region as economic profit, the growth of a tourism destination could bring a sense of pride for local communities - i.e., cherishing culture and history [26].

Furthermore, event tourism raises the attention and encourages local relationships; also, well-organized events could create a positive image of a tourism destination [34].

According to authors as Smith [35], government authorities on a national, regional, and local level significantly impact tourism development through their policy implementation. Moreover, though the relationship between the development of the tourism industry and socio-economic progress has been investigated and accepted as an existing association, this relationship's impact has not been studied to the degree that it is meaningful [35]. Preservation of the environment could likewise be made feasible by tourism activities creating an income [27]. According to Rizzi and Graziano [36, 37], the tourism industry popularises resources and creates new destination images in terms of regional and local economic development 


\subsection{Sustainable development and rural tourism in the Azores region}

Nowadays, in the Azores Autonomous Region, tourism management models and those for regional socio-economic development include the basic principles of sustainability, centering on preserving and conserving the islands' endogenous resources. Technical documents as the Regional Sustainable Development Plan for the Autonomous Region of the Azores (PREDSA), the Tourism Spatial Development Plan for the Autonomous Region of the Azores (POTRAA), the Research and Innovation Strategies for Smart Specialization in the Azores (RIS3 Azores), or the Strategic and Marketing Plan for Tourism in the Azores (PEMTA) completely stress these problems, addressing them proper benchmarks of regional development [38].

Scholars as Couto et al. [39] state that "the Azores have received several international awards and distinctions in recognition of the islands' sustainable development and sustainable tourism." Unique classifications and labels - i.e., Biosphere Reserve, OSPAR Convention, RAMSAR Convention, Natura 2000 Network, and World Heritage, have also been assigned to some natural areas and heritage sites. Lately, the Azores was designated the "Best Sustainable Destination in the Atlantic," a significant achievement for the Region's tourism and an acknowledgment of the quality of tourism on the islands, since the Azores' governing bodies continue to strengthen the destination's position regarding sustainability issues. Contextually, the process to approve the Region as a "Sustainable Destination" according to the Global Sustainable Tourism Council (GSTC) criteria is currently underway. Should it be granted, it will be an unprecedented certification of destinations in the archipelago, strengthening the Region as a benchmark destination and bringing with it new competitive advantages [38].

Nature-based tourism strengthens the Azores as a tourism destination, not only regarding the contemplative aspects and ecotourism but also through action and engaging activities. A tourist can quietly contemplate the islands' landscape, be very active, experience unforgettable emotions, and enjoy memorable experiences [40]. Thus, nature-based tourism, particularly the active segment, was selected as the Azores' tourism development priority product. As the core product in the region's strategy guides the destination's positioning and its promotional actions. In order to diversify the offering, nautical tourism, cultural and landscape touring, and health and wellness tourism were selected as complementary sectors [38].

Generally, the Azores' strategic planning as a tourist destination has been carried out with particular care regarding sustainability, despite some flaws. Due to the need to protect the region's competitive advantages - i.e., its natural assets and high levels of sustainability - a suitable model must be followed, at the same time as new products are developed, in order to increase the value of the experiences in the region and to boost the destination's ability to evolve. NEAT (Nature, Eco, and Adventure Tourism [41]), imbued with sustainability principles, can be critical products in this paradigm. These are the ideals that underlie the PEMTA, which has chosen active nature-based tourism as the destination's priority.

\section{METHODOLOGY}

Based on this study's scope, different approaches and methods were required, including direct and indirect analysis methods. Direct methods were used through site analysis and the implementation of the questionnaires. The indirect methods were used by analyzing the thematic literature.

Hence, the methodological framework was divided into four key levels: Interview design, data collection, case study analysis, and explanation of the results, concluding with the discussion and conclusions (Figure 1). The last stage converges on Public Administration and Decision-Makers' perceptions about the Potential of Rural Tourism Development in the Azores Region. From there, it was possible to propose some guidelines and suggestions for regional tourism planning.

\subsection{Interviews design and implementation}

The interview was designed considering online interviews. More precisely, we administered a web interview using Google Forms. Although online interviews are sensitive to biases in the results of an experimental study, such as in the respondents' age, this typology of the interview was selected due to social distancing in the actual pandemic crisis scenario requirements

The interviews focused on obtaining the Azores Public Administration and Decision-Makers' perceptions about the Potential of Rural Tourism Development through close-up questions and open but short answer questions.

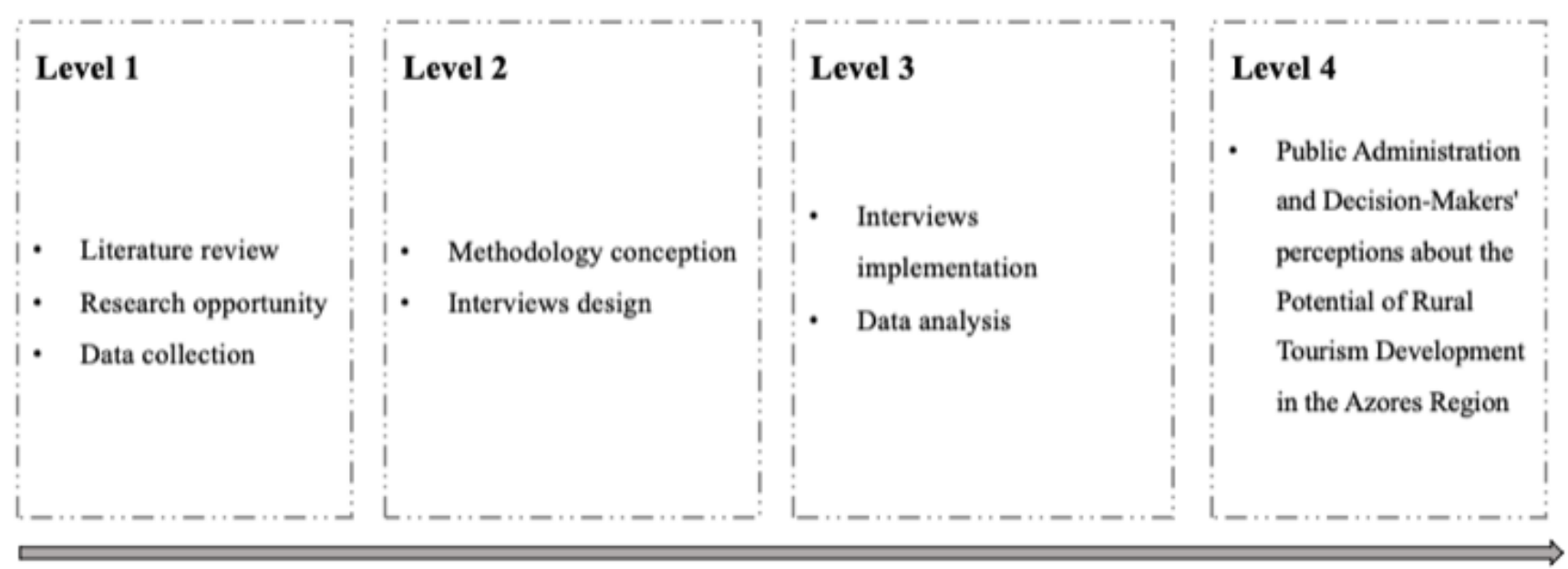

Figure 1. Different levels of the used methodology 
The sample group consisted of the Azores Public Administration and Decision-Makers, which we believe are the most relevant participants for this study typology. The sample was formed by 45 participants. The web interviews were carried out over May and December of 2020.

Recognizing the research's purpose, the authors decided to use short and direct inquiries regarding the Potential of Rural Tourism Development's perceptions in the Azores Region.

After the interview data have been collected, statistical analysis was first performed, applying in a first stage spreadsheet to arrange the assembled data and then filtered by statistical analysis utilizing the Statistical Package for the Social Sciences (SPSS).

\section{RESULTS}

The results listed below are given by direct analysis by the performed interviews.

The interview starts collecting the sociodemographic aspects of the participants (Table 1). Of the 45 participants in the study, $44.4 \%$ are female, and $55.6 \%$ male. The respondents were divided into three age groups: 18-35, 36-50, and 51-65. The most representative group was the 36-50-years-old group $(44.4 \%)$, followed by $18-35(37.8 \%)$, with the least representative age group being the 51-65 years (17.8\%). The participants' academic degree most representative was University education $(80.0 \%)$, and the least representative was basic education $(0.0 \%)$. Also, $97.8 \%$ of the participants were natives from the Azores Region.

In Table 2 are shown the three main aspects that respondents associate most with Rural Tourism, which are: (i) Bed and breakfast in a rural context (option marked by $80.0 \%$ of respondents and corresponds to $32.4 \%$ of the answers given); (ii) Country house $(71.1 \%$ of respondents; $28.8 \%$ of responses); and (iii) Rural Hotel or Guesthouse (44.4\% of respondents; $18.0 \%$ of responses).

Table 1. Sociodemographic aspects of the participants

\begin{tabular}{|c|c|c|c|c|}
\hline & Variables & $\mathbf{n}$ & $\%$ & Valid \% \\
\hline & \multicolumn{4}{|c|}{ Gender } \\
\hline \multirow{3}{*}{ Valid } & Female & 20 & 44.4 & 44.4 \\
\hline & Male & 25 & 55.6 & 55.6 \\
\hline & Total & 45 & $100.0 \%$ & $100.0 \%$ \\
\hline Missing & 99 & --- & --- & --- \\
\hline \multicolumn{2}{|r|}{ Total } & 45 & $100.0 \%$ & --- \\
\hline & \multicolumn{4}{|c|}{ Age Group } \\
\hline \multirow{4}{*}{ Valid } & $18-35$ & 17 & $37.8 \%$ & $37.8 \%$ \\
\hline & $36-50$ & 20 & $44.4 \%$ & $44.4 \%$ \\
\hline & $51-65$ & 8 & $17.8 \%$ & $17.8 \%$ \\
\hline & Total & 45 & $100.0 \%$ & $100.0 \%$ \\
\hline Missing & 99 & --- & --- & --- \\
\hline \multicolumn{2}{|r|}{ Total } & 45 & $100.0 \%$ & --- \\
\hline & \multicolumn{4}{|c|}{ Academic Degree } \\
\hline \multirow{4}{*}{ Valid } & Basic education & -- & -- & -- \\
\hline & High school & 9 & 20.0 & 20.0 \\
\hline & University education & 36 & 80.0 & 80.0 \\
\hline & Total & 45 & $100.0 \%$ & $100.0 \%$ \\
\hline Missing & 99 & --- & --- & --- \\
\hline \multicolumn{2}{|r|}{ Total } & 45 & $100.0 \%$ & $\begin{array}{ll}-- \\
--\end{array}$ \\
\hline & \multicolumn{4}{|c|}{ Native of Azores Autonomous Region } \\
\hline \multirow{3}{*}{ Valid } & No & 1 & 2.2 & 2.2 \\
\hline & Yes & 44 & 97.8 & 97.8 \\
\hline & Total & 45 & 100.0 & 100.0 \\
\hline Missing & 99 & --- & -- & --- \\
\hline \multicolumn{2}{|r|}{ Total } & 45 & $100.0 \%$ & --- \\
\hline
\end{tabular}

Table 2. Associations with rural tourism

\begin{tabular}{|c|c|c|c|c|}
\hline & & \multicolumn{2}{|c|}{ Responses } & \multirow{2}{*}{$\begin{array}{l}\text { Percentage of } \\
\text { Cases }\end{array}$} \\
\hline & & $\mathbf{n}$ & Percentage & \\
\hline \multirow[t]{6}{*}{$\begin{array}{l}\text { What do you associate most with Rural } \\
\text { Tourism? }\end{array}$} & $\begin{array}{l}\text { Activities such as (cycling, climbing, horse } \\
\text { riding, etc.) }\end{array}$ & 9 & $8.1 \%$ & $20.0 \%$ \\
\hline & Bed and breakfast in rural context & 36 & $32.4 \%$ & $80.0 \%$ \\
\hline & Country house & 32 & $28.8 \%$ & $71.1 \%$ \\
\hline & Rural Hotel or Guest House & 20 & $18.0 \%$ & $44.4 \%$ \\
\hline & Farm with animals & 13 & $11.7 \%$ & $28.9 \%$ \\
\hline & Other(s) & 1 & $0.9 \%$ & $2.2 \%$ \\
\hline Total & & 111 & $100.0 \%$ & $246.7 \%$ \\
\hline
\end{tabular}

Table 3. Closed-up questions (i)

\begin{tabular}{|c|c|c|c|c|c|}
\hline \multicolumn{6}{|c|}{ Question A: Have you ever had a Rural Tourism experience in the Azores? } \\
\hline & & Frequency & Percent & Valid Percent & Cumulative Percent \\
\hline \multirow{3}{*}{ Valid } & No & 19 & 42.2 & 43.2 & 43.2 \\
\hline & Yes & 25 & 55.6 & 56.8 & 100.0 \\
\hline & Total & 44 & 97.8 & 100.0 & - \\
\hline Missing & Do not know / Do not answer & 1 & 2.2 & - & - \\
\hline \multicolumn{2}{|r|}{ Total } & 45 & 100.0 & - & - \\
\hline \multicolumn{6}{|c|}{ Question A1: If you answered yes to the previous question, how would you rate it? } \\
\hline & & Frequency & Percent & Valid Percent & Cumulative Percent \\
\hline \multirow{5}{*}{ Valid } & Good & 4 & 8.9 & 16.0 & 16.0 \\
\hline & Excellent & 5 & 11.1 & 20.0 & 36.0 \\
\hline & Very Good & 15 & 33.3 & 60.0 & 96.0 \\
\hline & Satisfactory & 1 & 2.2 & 4.0 & 100.0 \\
\hline & Total & 25 & 55.6 & 100.0 & - \\
\hline Missing & - & 20 & 44.4 & - & - \\
\hline \multicolumn{2}{|r|}{ Total } & 45 & 100.0 & - & - \\
\hline
\end{tabular}


After, closed-up questions (i - Table 3 and ii - Table 4) were made to assess the participants' rural tourism experiences. Both tables presents two questions each (Table 3, questions A and $\mathrm{A} 1$, and Table 4, questions B and B1). More than half $(56.8 \%)$ of the Decision-makers and Public Administrators respondents reported that they had already had some (at least one) experience of Rural Tourism in the Azores. Of these, $60.0 \%$ rated the experience lived in this context as "Very Good," 20.0\% as "Excellent," $16.0 \%$ as "Good" and $4.0 \%$ as "Satisfactory," thus, leaving the possibility of improving the experience/offer of Rural Tourism in the Azores Region (Table 3).

In this regard, through the analysis of Table 4 it is possible to understand that the vast majority believe that rural tourism has increased in the Azores Region's last decade (90.2\%). Regional development has been positive and has positively impacted the local population $(97.6 \%)$.

In order to understand which activities and themes contributed the most to the Azores Region's development in the last years, an open question was made, and the answers were grouped by thematic options (Table 5). The decision to group the answers by themes was due to the considerable number of different answers collected - once, this was an open question in the interview. In the opinion of the respondents, it is possible to verify that the investment on tourism was the option that most contributed to this development.

Table 4. Closed-up questions (ii)

Question B: Do you believe that rural tourism has increased in the Azores Region's last decade from a comparative perspective?

\begin{tabular}{|c|c|c|c|c|c|}
\hline 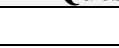 & -1 & Frequency & Percent & Valid Percent & Cumulative Percent \\
\hline \multirow{3}{*}{ Valid } & No & 4 & 8.9 & 9.8 & 9.8 \\
\hline & Yes & 37 & 82.2 & 90.2 & 100.0 \\
\hline & Total & 41 & 91.1 & 100.0 & - \\
\hline Missing & Do not know / Do not answer & 4 & 8.9 & - & - \\
\hline \multicolumn{2}{|r|}{ Total } & 45 & 100.0 & - & - \\
\hline
\end{tabular}

\begin{tabular}{l} 
Question B1: From a comparative perspective, with the last decade, do you believe that regional development was positive and created \\
positive impacts on the local population? \\
\hline \multirow{3}{*}{ Valid }
\end{tabular}

Table 5. Activities that contributed the most for the development - grouped options

\begin{tabular}{c|c}
\hline Options (1-4) & $\mathbf{\%}$ \\
\hline Bureaucracy and related & $20.0 \%$ \\
\hline Endogenous resources & $30.0 \%$ \\
\hline External funding & $3.3 \%$ \\
\hline Invest on tourism & $46.6 \%$ \\
\hline
\end{tabular}

Table 6. Main aspects that lead tourists to choose the Azores to carry out their experience of Rural Tourism

\begin{tabular}{|c|c|c|c|c|}
\hline & Variables & $\mathbf{n}$ & $\%$ & Valid \% \\
\hline & \multicolumn{4}{|c|}{ Adventure related activities } \\
\hline \multirow{3}{*}{ Valid } & No & 17 & 37.8 & 37.8 \\
\hline & Yes & 28 & 62.2 & 62.2 \\
\hline & Total & 45 & $100.0 \%$ & $100.0 \%$ \\
\hline Missing & 99 & --- & --- & --- \\
\hline \multicolumn{2}{|c|}{ Total } & 45 & $100.0 \%$ & --- \\
\hline & \multicolumn{4}{|c|}{$\begin{array}{l}\text { Classification of the destination on the Internet } \\
\text { and in books/guides }\end{array}$} \\
\hline \multirow{3}{*}{ Valid } & No & 5 & 11.1 & 11.1 \\
\hline & Yes & 40 & 88.9 & 88.9 \\
\hline & Total & 45 & $100.0 \%$ & $100.0 \%$ \\
\hline Missing & 99 & --- & --- & --- \\
\hline \multicolumn{2}{|c|}{ Total } & 45 & $100.0 \%$ & --- \\
\hline & \multicolumn{4}{|c|}{ Weather } \\
\hline \multirow{3}{*}{ Valid } & No & 18 & 40.0 & 40.9 \\
\hline & Yes & 26 & 57.8 & 59.1 \\
\hline & Total & 44 & 97.8 & $100.0 \%$ \\
\hline Missing & 99 & 1 & 2.2 & --- \\
\hline \multicolumn{2}{|c|}{ Total } & 45 & $100.0 \%$ & --- \\
\hline & \multicolumn{4}{|c|}{ Culture } \\
\hline
\end{tabular}

\begin{tabular}{|c|c|c|c|c|}
\hline \multirow{3}{*}{ Valid } & No & 13 & 28.9 & 29.5 \\
\hline & Yes & 31 & 68.9 & 70.5 \\
\hline & Total & 44 & 97.8 & $100.0 \%$ \\
\hline Missing & 99 & 1 & 2.2 & --- \\
\hline \multicolumn{2}{|c|}{ Total } & 45 & $100.0 \%$ & --- \\
\hline & \multicolumn{4}{|c|}{ Gastronomy } \\
\hline \multirow{3}{*}{ Valid } & No & 14 & 31.1 & 31.1 \\
\hline & Yes & 31 & 68.9 & 68.9 \\
\hline & Total & 45 & $100.0 \%$ & $100.0 \%$ \\
\hline Missing & 99 & --- & --- & --- \\
\hline \multicolumn{2}{|c|}{ Total } & 45 & $100,0 \%$ & --- \\
\hline & \multicolumn{4}{|c|}{ Landscape } \\
\hline \multirow{3}{*}{ Valid } & No & 0 & 0.0 & 0.0 \\
\hline & Yes & 45 & 100.0 & 100.0 \\
\hline & Total & 45 & $100.0 \%$ & $100.0 \%$ \\
\hline Missing & 99 & --- & --- & --- \\
\hline \multicolumn{2}{|c|}{ Total } & 45 & $100.0 \%$ & - \\
\hline & \multicolumn{4}{|c|}{$\begin{array}{l}\text { On the recommendation of others / Based on the } \\
\text { experiences of others }\end{array}$} \\
\hline \multirow{3}{*}{ Valid } & No & 6 & 13.3 & 13.3 \\
\hline & Yes & 39 & 86.7 & 86.7 \\
\hline & Total & 45 & $100.0 \%$ & $100.0 \%$ \\
\hline Missing & 99 & --- & --- & --- \\
\hline \multicolumn{2}{|c|}{ Total } & 45 & $100.0 \%$ & - \\
\hline & \multicolumn{4}{|c|}{ Other } \\
\hline \multirow{3}{*}{ Valid } & No & 26 & 57.8 & 59.1 \\
\hline & Yes & 18 & 40.0 & 40.9 \\
\hline & Total & 44 & 97.8 & $100.0 \%$ \\
\hline Missing & 99 & 1 & 2.2 & --- \\
\hline \multicolumn{2}{|c|}{ Total } & 45 & $100.0 \%$ & --- \\
\hline
\end{tabular}

In this sense, the participants were also asked about the main aspects that lead tourists to choose the Azores to carry out the 
Rural Tourism experience (Table 6). In the perception of respondents, the main aspects that lead tourists to choose the Azores to carry out their experience of Rural Tourism are the Landscape (100\% of respondents), Classification of the destination on the Internet and in books/guides (88.9\%), On the recommendation of others / Based on the experiences of others (86.7\%), Culture (70.5\%) and Gastronomy (68.9\%).

Furthermore, it was carried out an Ascendant Hierarchical Cluster Analysis (AHCA) of the items of Table 6. These items assessed the aspects that lead tourists to choose the Azores to carry out their rural tourism experience. Therefore, this analysis was carried out based on the Ochiai coefficient (Table 7) and in the aggregation criteria Single-Linkage, CompleteLinkage, and Average-Linkage [42].

According to the values of the global statistics of levels, STAT (e.g., $[43,44]$, the best partition (STAT $=4,1713$ ) is the following partition into 4 clusters (level 4 ), obtained by all used aggregation criteria:

- Cluster 1: \{2-Classification of the destination on the internet and/or in books/guides, 6-Landscape, 7-On the recommendation of others / Based on experiences of others, 4-Culture, 5-Gastronomy $\}$;

- Cluster 2: $\{1-$ Adventure related activities $\}$;

- Cluster 3: $\{3$-Weather $\}$;

- Cluster 4: $\{8$-Other $\}$.

Figure 2 shows the dendrogram provided by Singe-Linkage method. It should be noted that the first cluster contains the five main aspects that lead tourists to choose the Azores to carry out their experience of Rural Tourism, and that the remaining three clusters are singletons. Thus, the preservation of the landscape, culture and gastronomy must be a strong bet, as well as the updating, creating or / and maintaining high quality web sites and books / guides. On the other hand, the offer of Adventure related activities may also be a differential factor in terms of choosing the Azores for the more adventurous.

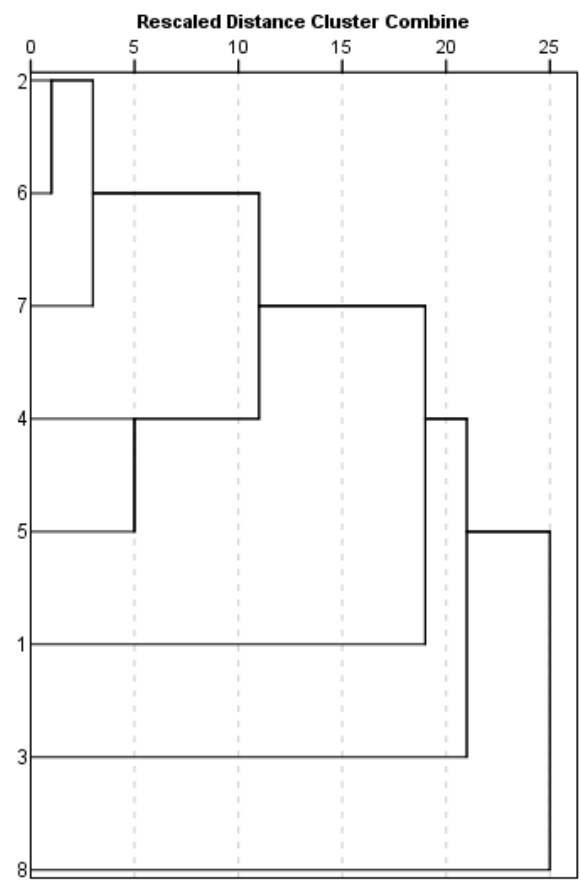

1- Adventure related activities; 2- Classification of the destination on the internet and/or in books/guides; 3 Weather; 4-Culture; 5-Gastronomy; 6-Landscape; 7- On the recommendation of others / Based on experience of others; 8-Other

Figure 2. Dendrogram using Average-Linkage (Between groups) method

Table 7. Proximity matrix containing the values of the Ochiai coefficient between pairs of items

\begin{tabular}{c|c|c|c|c|c|c|c|c}
\hline Items & $\mathbf{1}$ & $\mathbf{2}$ & $\mathbf{3}$ & $\mathbf{4}$ & $\mathbf{5}$ & $\mathbf{6}$ & $\mathbf{7}$ & $\mathbf{8}$ \\
\hline $\mathbf{1}$ & 1.000 & 0.740 & 0.642 & 0.588 & 0.632 & 0.783 & 0.749 & 0.544 \\
\hline $\mathbf{2}$ & 0.740 & 1.000 & 0.691 & 0.777 & 0.760 & 0.941 & 0.883 & 0.642 \\
\hline $\mathbf{3}$ & 0.642 & 0.691 & 1.000 & 0.634 & 0.680 & 0.769 & 0.668 & 0.555 \\
\hline $\mathbf{4}$ & 0.588 & 0.777 & 0.634 & 1.000 & 0.885 & 0.839 & 0.816 & 0.593 \\
\hline $\mathbf{5}$ & 0.632 & 0.760 & 0.680 & 0.885 & 1.000 & 0.826 & 0.800 & 0.689 \\
\hline $\mathbf{6}$ & 0.783 & 0.941 & 0.769 & 0.839 & 0.826 & 1.000 & 0.929 & 0.640 \\
\hline $\mathbf{7}$ & 0.749 & 0.883 & 0.668 & 0.816 & 0.800 & 0.929 & 1.000 & 0.688 \\
\hline $\mathbf{8}$ & 0.544 & 0.642 & 0.555 & 0.593 & 0.689 & 0.640 & 0.688 & 1.000 \\
\hline
\end{tabular}

Table 8. The most relevant aspects for a Rural Tourism activity's success in the Azores Region

\begin{tabular}{|c|c|c|c|c|}
\hline Aspects for a Rural Tourism activity's Success & Mode(s) & $\mathbf{P 2 5}$ & P50 & P75 \\
\hline a. Accommodation and certified activity, or related to a brand & 3 & 3 & 3 & 4 \\
\hline b. Location or region well known for tourism & 3 & 3 & 3 & 4 \\
\hline c. Nearby cultural attractions & 3 & 2 & 3 & 3 \\
\hline d. Good location of the accommodation & 3 & 3 & 3 & 4 \\
\hline e. Telephone and Internet coverage & 3 & 3 & 3 & 4 \\
\hline f. Condition of Infrastructures & 4 & 3 & 4 & 4 \\
\hline g. Frequency and quality of Events taking place in the area & 3 & 2 & 2 & 3 \\
\hline h. Accessibility & 3 and 4 & 3 & 3 & 4 \\
\hline i. Location and quiet and calm surroundings & 4 & 3 & 4 & 4 \\
\hline j. Attractive Landscape & 4 & 3.25 & 4 & 4 \\
\hline k. Easy, safe, and secure booking process - transparent & 4 & 3 & 4 & 4 \\
\hline 1. Proximity to sports infrastructures & 2 & 2 & 2 & 2 \\
\hline m. Proximity to places of entertainment (Bars, discotheques, etc.) & 2 & 2 & 2 & 2 \\
\hline n. Feedback from another tourists & 3 & 3 & 3 & 4 \\
\hline o. Health services available nearby & 3 & 3 & 3 & 3 \\
\hline p. Value & 3 & 3 & 3 & 4 \\
\hline q. Other & 1 & 1 & 2 & 3 \\
\hline
\end{tabular}


Also, a question about which was the most relevant aspects for a Rural Tourism activity's success was asked (Table 8). In this regard, the aspects that respondents (Decision-makers and Public Administration) most values for the success of an activity related to Rural Tourism are the Attractive Landscape, the Condition of Infrastructures, Location and quiet and calm surroundings, and Easy, safe, and secure booking process transparent. On the other hand, the aspects that they least value are the aspects included in the "Other" category, Proximity to sports infrastructures, Proximity to places of entertainment (Bars, discotheques, etc.), as well as the Frequency and quality of Events taking place in the area.

Contextually, and based on the critical factors identified by Castanho et al. [45] for territorial success in peripheral territories, the participants were asked to address their importance to each one of those factors for the success of the ultra-peripheral region of the Azores (Table 9). About the success of the Rural Tourism activity in the Azores, respondents (decision-makers and public administration) assign greater importance to the following factors, considered critical for success and territorial sustainability: "Protection and conservation of Nature" and "Greater commitment and political transparency." On the other hand, they attribute less importance to factors in the "Other" category.

Moreover, a question was made to the participants to understand which is in their perception the best channel to divulgate the Rural Tourism (Figure 3). The majority (55.6\%) of respondents believe that the most crucial channel in disseminating Rural Tourism activity is the one referring to booking pages/websites. In the perception of the decisionmakers / Public Administration surveyed, the second most important channel is the one related to social networks (e.g., Facebook, Instagram, ...), as shown in Figure 3.

Besides, the interview has two questions regarding which factors could influence negatively (Table 10) and positively (Table 11) the activity of Rural Tourism in the Azores. In the perception of the respondents, the factors that can most negatively influence the activity of Rural Tourism in the Azores are Accessibility and transport (option marked by more than half of the respondents $(53.3 \%$ ); corresponds to $18.5 \%$ of the answers); Resistance to change by the population $(28.9 \%$ of respondents); Regional policies (28.9\%); Monopolization of the Rural Tourism activity (28.9\%); and the economic power of the consumer (an option highlighted by almost $1 / 4$ of the respondents $(24.4 \%)$.

In the perception of respondents, the factors that can most positively influence the activity of Rural Tourism in the Azores are Marketing (option marked by $66.7 \%$ of individuals), Skilled labor (60\%), Accessibility and transport $(53.3 \%)$, Regional policies $(26.7 \%)$ and Local policies $(22.2 \%)$. Also, it should be noted that the workforce qualification (low or high) can negatively or positively affect the activity of Rural Tourism in the Azores, as well as the accessibility and transport (bad or good), can negatively or positively affect the activity of Rural Tourism in the Azores.

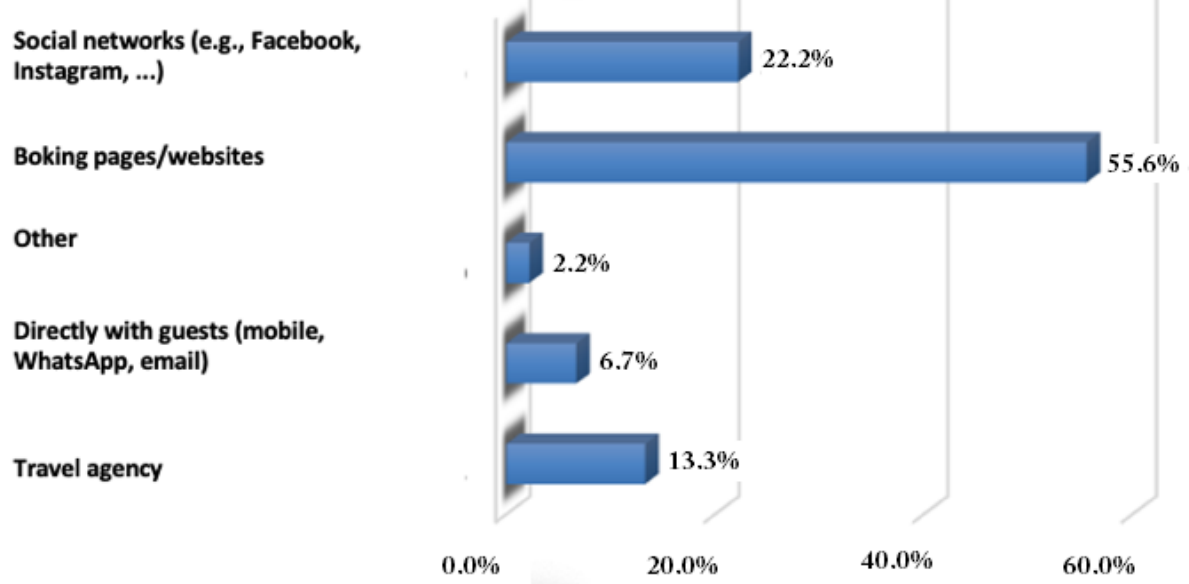

Figure 3. Distribution of respondents according to the Rural Tourism activity dissemination channel that they consider most important

Table 9. The critical factors for the success of the ultra-peripheral region of the Azores, in the perspective of the respondents

\begin{tabular}{|c|c|c|c|c|}
\hline Factors for the Success of Rural Tourism in the Azores Region & Mode(s) & $\mathbf{P 2 5}$ & P50 & P75 \\
\hline i. Connectivity - Movement and displacements (between urban centers, islands, etc.) & 3 & 3 & 3 & 4 \\
\hline ii. Strengthening of the Regional Territorial Strategy & 3 & 3 & 3 & 4 \\
\hline iii. Avoid duplication of infrastructure in the Region & 3 & 2,5 & 3 & 4 \\
\hline iv.. Sense of Belonging of the Residents & 3 & 3 & 3 & 3,5 \\
\hline v. Offer Diversification & 3 & 3 & 3 & 4 \\
\hline vi. Ease of Access to Regional Funds & 3 & 3 & 3 & 4 \\
\hline vii Strengthening the Economy & 3 & 3 & 3 & 4 \\
\hline viii. Standards of life quality & 3 & 3 & 3 & 4 \\
\hline ix. Magnet for Young and Talented People & 3 & 3 & 3 & 4 \\
\hline x. Definition of common objectives and strategies (between public administration-entrepreneurs-population) & 3 & 3 & 3 & 4 \\
\hline xi. Greater political commitment and transparency & 4 & 3 & 4 & 4 \\
\hline xii. Protection and conservation of Nature & 4 & 4 & 4 & 4 \\
\hline xiii. Public participation & 3 & 3 & 3 & 4 \\
\hline xiv. Marketing and advertisement & 3 & 3 & 3 & 4 \\
\hline xv. Other & 1 & 1 & 2 & 3 \\
\hline
\end{tabular}


So, the study also analyzed which is the modality that contributes the most to the development of the Region Rural Tourism (Table 12). in the perception of $73.7 \%$ (approximately 74\%) of the respondents, the modality of Tourism that most contributes to the development and socioeconomic strengthening of the Region is Rural Tourism.

Contextually, two questions were made regarding identifying the main benefits of this typology of tourism, from the participants' point of view, for the Region (Table 13) and the local communities (Table 14).

In the perception of the respondents (Decision-makers and Public Administration), the main benefits of this type of tourism for the Region are, in order of importance, the "Job creation" (option marked by $60 \%$ of respondents; corresponds to $20 \%$ of the total of valid answers), the "Attraction of new tourists" (option marked by $44.4 \%$ of the respondents), the "Development of trade, services, and activities" (42.2\%) and "Strengthening of the regional economy" (40\%).

In the perception of respondents (Decision-makers and Public Administration), the main benefits of this type of tourism for local communities are Job creation (option marked by $68.9 \%$ of respondents), Strengthening the local economy $(68.9 \%)$, To counter local desertification $(42.2 \%)$ and the development of trade, services and activities (40\%).

Table 10. The factors that could influence negatively the activity of Rural Tourism in the Azores, in the respondents perspective

\begin{tabular}{|c|c|c|c|c|}
\hline & & \multicolumn{2}{|c|}{ Responses } & \multirow[t]{2}{*}{ Percentage of Cases } \\
\hline & & $\mathbf{n}$ & Percentage & \\
\hline \multirow{11}{*}{ Monopolization of the activity of Rural Tourisma } & Financial capital & 8 & $6.2 \%$ & $17.8 \%$ \\
\hline & Marketing & 3 & $2.3 \%$ & $6.7 \%$ \\
\hline & Skilled labor & 10 & $7.7 \%$ & $22.2 \%$ \\
\hline & Accessibility and transport & 24 & $18.5 \%$ & $53.3 \%$ \\
\hline & Technology & 2 & $1.5 \%$ & $4.4 \%$ \\
\hline & Support networks & 8 & $6.2 \%$ & $17.8 \%$ \\
\hline & External dependency & 19 & $14.6 \%$ & $42.2 \%$ \\
\hline & Resistance to change by the population & 13 & $10.0 \%$ & $28.9 \%$ \\
\hline & Local policies & 6 & $4.6 \%$ & $13.3 \%$ \\
\hline & Regional policies & 13 & $10.0 \%$ & $28.9 \%$ \\
\hline & Monetary power of the consumer & 11 & $8.5 \%$ & $24.4 \%$ \\
\hline \multicolumn{2}{|l|}{ Total } & 130 & $100.0 \%$ & $288.9 \%$ \\
\hline
\end{tabular}

a. Group

Table 11. The factors that could influence positively the activity of Rural Tourism in the Azores, in the respondents perspective

\begin{tabular}{|c|c|c|c|c|}
\hline & & \multicolumn{2}{|c|}{ Responses } & \multirow[t]{2}{*}{$\begin{array}{c}\text { Percentage of } \\
\text { Cases }\end{array}$} \\
\hline & & $\mathbf{n}$ & Percentage & \\
\hline \multirow{10}{*}{$\begin{array}{c}\text { Monopolization of the activity of Rural } \\
\text { Tourism }^{\mathrm{a}}\end{array}$} & Financial capital & 8 & $6.0 \%$ & $17.8 \%$ \\
\hline & Marketing & 30 & $22.4 \%$ & $66.7 \%$ \\
\hline & Skilled labor & 27 & $20.1 \%$ & $60.0 \%$ \\
\hline & Accessibility and transport & 24 & $17.9 \%$ & $53.3 \%$ \\
\hline & Technology & 6 & $4.5 \%$ & $1303 \%$ \\
\hline & Support networks & 8 & $6.0 \%$ & $1708 \%$ \\
\hline & External dependency & 1 & $0.7 \%$ & $2.2 \%$ \\
\hline & Local policies & 10 & $7.5 \%$ & $22.2 \%$ \\
\hline & Regional policies & 12 & $9.0 \%$ & $26.7 \%$ \\
\hline & Monetary power of the consumer & 7 & $5.2 \%$ & $15.6 \%$ \\
\hline & $\begin{array}{c}\text { Monopolization of Rural Tourism } \\
\text { activity }\end{array}$ & 1 & $0.7 \%$ & $2.2 \%$ \\
\hline \multicolumn{2}{|c|}{ Total } & 134 & $100.0 \%$ & $297.8 \%$ \\
\hline
\end{tabular}

Table 12. The modality that contributes the most to the development of the Region Rural Tourism, in the participants' perspectives

\begin{tabular}{|c|c|c|c|c|}
\hline & & Frequency & Percentage & Valid Percentage \\
\hline \multirow{6}{*}{ Valid } & Scientific Tourism (e.g. conferences, congresses, seminars, etc.) & 4 & 8.9 & 10.5 \\
\hline & Health Tourism & 1 & 202 & 2.6 \\
\hline & Sports Tourism (e.g. surfing) & 2 & 4.4 & 5.3 \\
\hline & Mass Tourism & 3 & 6.7 & 7.9 \\
\hline & Rural Tourism & 28 & 6202 & 73.7 \\
\hline & Total & 38 & 84.4 & 100.0 \\
\hline Missing & 99 & & & \\
\hline \multicolumn{2}{|r|}{ Total } & 45 & 100.0 & - \\
\hline
\end{tabular}


Table 13. The main benefits of rural tourism for the Azores Region from the participants' point of view

\begin{tabular}{|c|c|c|c|c|}
\hline & & \multicolumn{2}{|c|}{ Responses } & \multirow{2}{*}{ Responses } \\
\hline & & $\mathbf{n}$ & $\mathbf{n}$ & \\
\hline \multirow[t]{9}{*}{$\begin{array}{c}\text { Linked } \\
\text { answers }^{\mathrm{a}}\end{array}$} & Attraction of new tourists & 20 & $14.8 \%$ & $44.4 \%$ \\
\hline & Counteract the local desertification & 12 & $8.9 \%$ & $26.7 \%$ \\
\hline & Job creation & 27 & $20.0 \%$ & $60.0 \%$ \\
\hline & Development of trade, services and activities & 19 & $14.1 \%$ & $42.2 \%$ \\
\hline & Location disclosure & 14 & $10.4 \%$ & $31.1 \%$ \\
\hline & Strengthening the local economy & 18 & $13.3 \%$ & $40.0 \%$ \\
\hline & Cultural exchange & 1 & $0.7 \%$ & $2.2 \%$ \\
\hline & $\begin{array}{c}\text { Preservation, conservation and enhancement of Culture (Crafts, Gastronomy, } \\
\text { Architecture) }\end{array}$ & 11 & $8.1 \%$ & $24.4 \%$ \\
\hline & Nature preservation, conservation and enhancement & 13 & $9.6 \%$ & $28.9 \%$ \\
\hline & Total & 135 & $100.0 \%$ & $300.0 \%$ \\
\hline
\end{tabular}

Table 14. The main benefits of rural tourism for the Azores Local Communities from the participants' point of view

\begin{tabular}{|c|c|c|c|c|}
\hline & & \multicolumn{2}{|c|}{ Responses } & \multirow{2}{*}{ Responses } \\
\hline & & $\mathbf{n}$ & $\mathbf{n}$ & \\
\hline \multirow[t]{9}{*}{$\begin{array}{c}\text { Linked } \\
\text { answers }^{\mathrm{a}}\end{array}$} & Attraction of new tourists & 5 & $3.7 \%$ & $11.1 \%$ \\
\hline & Counteract the local desertification & 19 & $14.1 \%$ & $42.2 \%$ \\
\hline & Job creation & 31 & $23.0 \%$ & $68.9 \%$ \\
\hline & Development of trade, services and activities & 18 & $13.3 \%$ & $40.0 \%$ \\
\hline & Location disclosure & 10 & $7.4 \%$ & $22.2 \%$ \\
\hline & Strengthening the local economy & 31 & $23.0 \%$ & $68.9 \%$ \\
\hline & Cultural exchange & 5 & $3.7 \%$ & $11.1 \%$ \\
\hline & $\begin{array}{l}\text { Preservation, conservation and enhancement of Culture (Crafts, Gastronomy, } \\
\text { Architecture) }\end{array}$ & 8 & $5.9 \%$ & $17.8 \%$ \\
\hline & Nature preservation, conservation and enhancement & 8 & $5.9 \%$ & $17.8 \%$ \\
\hline & Total & 135 & $100.0 \%$ & $300.0 \%$ \\
\hline
\end{tabular}

\section{DISCUSSION AND CONCLUSIONS}

At the end of the 90 s of the 20th century and the first decade of the 21 st century, there was an effective convergence of the Azores' regional economy concerning Portugal and the European Union. The dynamics of growth in that period led the Azores to a close approximation to the values of creating national and community wealth. However, this momentum slowed down, and compared to Portugal, between 2010 and 2018 , it did not show any evolution, even showing a setback compared to the European Union.

In the year 2000, the regional GDP only represented $1.9 \%$ of the country's wealth, while in 2018, this value reached $2.1 \%$. The variation in GDP per capita is more expressive since this indicator in the Azores $(9,979 €)$ corresponded to $80 \%$ of the national value $(12,480 €)$ at the beginning of the century. Currently, it reaches $88 \%(17,514 €)$. If we go further back in time, it appears that in 1995 the GDP per capita in the Azores was only 6,894 euros compared to 8,880 euros at the national level $(78 \%)$. Thus, there is a significant evolution in the capacity to create wealth, even in great economic instability - i.e., the period between 2007 and 2012, whose impact on small and fragile economies - such as the Azorean is amplified. Due to this impact, there was a stagnation in the Region's evolution vis-à-vis national results.

Regarding the Purchasing Power Parity (PPP), the Autonomous Region of Azores GDP per capita has historically remained below $75 \%$ of the EU average of 28 . This performance classifies the Region as one of the least developed regions in the Community space, configuring criteria for allocating resources from the Structural and Investment Funds, which have proved to be a fundamental lever for the regional economy, as evidenced by the survey developed in this study.

The Region's economic dynamics naturally directly impact the labor market, both in terms of opportunities and the quality of the jobs created. Job creation in the Azores followed the trend of economic growth until 2009. As of 2010, there was a significant reduction in this indicator due to the substantial impacts of the regional economic and financial crisis, bringing the number of people employed closer to the values registered in 2000. Unemployment contributed to this reduction in the civil construction sector, which had a low schooling rate, making it difficult for many individuals who lost their jobs to new opportunities in the labor market.

Despite reaching the largest number of employed people in 2019, unemployment remains a significant challenge for the regional economy. Since 2003, there has been a growing trend. However, the shock waves that resulted from the international economic and financial crisis, with profound effects on the regional economy, have led to historically high unemployment rates in the Azores. In 2000, the unemployment rate was less than $4 \%$. However, in the first quarter of 2014 , it reached $18 \%$, the country's highest. From that moment on, there were several decreases in this indicator, setting it, in the third quarter of 2020 , at $6,7 \%$ (still higher than the values recorded before the crisis, due to the active population's growth).

One of the major structural problems of Azorean society and which directly influences combating unemployment is the level of qualification of the population, which the present 
study reflects as one of the significant challenges to be overcome. The comparison between the data from the 2001 and 2011 Censuses reveals a clear evolution in this reality, but the qualification of human resources remains very low, with only $8.2 \%$ of the population having completed higher education. The number of individuals with qualifications from secondary education is less than $20 \%$ (19.1\%). This situation makes it difficult to identify qualified labor for companies, especially considering the new trends in activities developed in rural tourism.

Tourism thus appears as a sector with great potential, given the installed capacity and the existing natural potential However, it will be necessary to reinforce the focus on qualifying the destination, which includes preparing the population and professionals in the sector.

In fact, tourism is an important strategic sector for the Azores and can make a crucial contribution to the region's development and growth. Fundamental changes have recently been made to the sector's operating structure, paving the way for historical growth and opening new doors to the world [38]

Contextually, the projection of the economic development of the Azores defines tourism as one of its strategic pillars. As an example, there is the regional Smart Specialization Strategy. The islands' natural characteristics, the existing comparative gains, and the growing tertiarization of the economy made this decision an easily understandable option. The evolution recorded shows the great potential for creating value in this sector and leveraging the regional economy, especially concerning rural tourism.

This article is the first to explore public administration and decision-makers' perceptions about the potential of rural tourism development in the Azores Region from an academic perspective. Through the analysis, it is possible to understand that the vast majority believe that rural tourism has increased in the Azores Region's last decade. Regional development has been positive and has positively impacted the local population.

In the perception of the respondents (Decision-makers and Public Administration), the main benefits of this type of tourism for the Region are, in order of importance, the "Job creation," the "Attraction of new tourists," the "Development of trade, services, and activities "and" Strengthening of the regional economy. "

Furthermore, nature tourism, ecotourism, and adventure tourism, imbued with the principles of sustainability, can be critical products in this paradigm. These are key ideals that underlie PEMTA, which has chosen nature tourism as the priority product for the destination, in addition to reiterating the importance of sustain- ability for the continuous improvement and valuation thereof. Also, bearing in mind the need to protect the region's competitive advantages - i.e., natural assets and high levels of sustainability; it is essential that a suitable model is followed and new products that increase the value of experiences in the region and boost the destination's position continue to be developed [6, 24, 38].

Thereby, the design of future regional plans that aim at sustainable development must definitely consider the factors identified in the present study concerning rural tourism.

\section{ACKNOWLEDGMENTS}

This paper is financed by Portuguese national funds through FCT-Fundação para a Ciência e a Tecnologia, I.P., project number UIDB/00685/2020 and also by the project GREAT-
Genuine Rural Experiences in the Azores Tourism, with the code: ACORES-01-0145-FEDER-000089.

\section{REFERENCES}

[1] Morais, J., Castanho, R., Pinto-Gomes, C., Santos, P. (2018). Merging traditional livelihood activities with new employment opportunities brought by ecotourism to Iona national park, Angola: Rethinking social sustainability. Chapter in the Book: Planeamiento Sectorial: Recursos Hídricos, Espacio Rural Y Fronteras. Ed. Thomson Reuteurs Aranzadi. pp. 293-303.

[2] Morais, J., Castanho, R.A., Loures, L., Pinto-Gomes, C., Santos, P. (2019). Villagers' perceptions of tourism activities in Iona national park: Locality as a key factor in planning for sustainability. Sustainability, 11(16): 4448. https://doi.org/10.3390/su11164448

[3] Santos, R., Castanho, R.A., Lousada, S. (2019). Return migration and tourism sustainability in Portugal: extracting opportunities for sustainable common planning in southern Europe. Sustainability, 11(22): 6468. https://doi.org/10.3390/su11226468

[4] Santos, R., Castanho, R.A., Lousada, S. (2020). The Portuguese emigrants' return and the impacts over tourism development in rural areas: Directions for a sustainable planning. Chapter 5 (pp. 85-100). In the Book: Espacios y Sociedades en Transformación. Ed. Thomson Reuters Aranzadi - Spain.

[5] Couto, G., Castanho, R.A., Sousa, A., Pimentel, P., Santos, C., Carvalho, C. (2020). The impacts of COVID19 crisis over the tourism expectations of the Azores archipelago residents. Sustainability, 12(18): 7612. https://doi.org/10.3390/su12187612

[6] Couto G., Castanho R.A., Pimentel P., Carvalho C.B., Sousa Á. (2021). The Potential of Adventure Tourism in the Azores: Focusing on the Regional Strategic Planning. In: Abreu A., Liberato D., González E.A., Garcia Ojeda J.C. (eds) Advances in Tourism, Technology and Systems. ICOTTS 2020. Smart Innovation, Systems and Technologies, vol 209. Springer, Singapore. https://doi.org/10.1007/978-981-33-4260-6_2

[7] Ulucak, R., Yücel, A.G., İlkay, S.Ç. (2020). Dynamics of tourism demand in Turkey: Panel data analysis using gravity model. Tourism Economics, 26(8): 1394-1414. https://doi.org/10.1177/1354816620901956

[8] Cavaco, C. (2003). Habitares dos Espaços Rurais. Revista da Faculdade de Letras-Geografia. 1 série, XIX, pp. 47-64.

[9] Labrianidis, L., Ferrão, J., Hertzina, K., Kalantaridis, C., Piasecki, B., Sma-llbone, D. (2003). The Future of Europe's Rural Periphery. Final Report. 5th Framework Programme of the European Community.

[10] Sharpley, R., Vass, A. (2006). Tourism, farming and diversification: An attitudinal study. Tourism Management, 27(5): 1040-1052. https://doi.org/10.1016/j.tourman.2005.10.025

[11] Grek, J., Karlsson, C., Klaesson, J. (2009). Market potential and new firm formation. Working Paper Series in Economics and Institutions of Innovation 202. Royal Institute of Technology, CESIS - Centre of Excellence for Science and Innovation Studies.

[12] Williams, A. (1984). Introduction. In Williams, A. (Ed.), Southern Europe Transformed-Political and Economic 
Change in Greece, Italy, Portugal and Spain, 1-32. Harper \& Row, London.

[13] Bergstrom, J., Cordell, K., Ashley, G., Watson, A. (1990). Economic impacts of recreational spending on rural areas: A case study. Economic Development Quarterly, 4(1): 29-39. https://doi.org/10.1177/089124249000400104

[14] Fleischer, A., Felsenstein, D. (2000). Support for rural tourism - does it make a difference? Annals of Tourism Research, 27(4): 1007-1024. https://doi.org/10.1016/S0160-7383(99)00126-7

[15] Mahony, K., Zyl, J. (2002). The impacts of tourism investment on rural communities: Three case studies in South Africa. Development Southern Africa, 19 (1): 83 103. https://doi.org/10.1080/03768350220123891

[16] Mazumder, H., Ahmed, M., Al-Amin, Q. (2009). Estimating total contribution of tourism to Malaysia economy. International Journal of Business, Management and Social Sciences, 2(3): 146-159.

[17] Vanegas, M., Croes, R. (2003). Growth, development and tourism in a small economy: Evidence from Aruba. International Journal of Tourism Research, 5(5): 315-330. https://doi.org/10.1002/jtr.441

[18] Reeder, R., Brown, D. (2005). Recreation, tourism, and rural well-being. Economic Research Report Number 7. Department of Agriculture. United States.

[19] Kilkenny, M., Partridge, M. (2009). Export sectors and rural development. American Journal of Agricultural Economics, 91: 910-929.

[20] Santos, R. (2013). O regresso dos emigrantes portugueses e o desenvolvimento do turismo em Portugal. Ph.D. Thesis. Portugal. University of Aveiro.

[21] Loures, L., Castanho, R.A., Vulevic, A., Naranjo Gómez, J., Cabezas, J., Fernández-Pozo, L. (2018). The multivariated effect of city cooperation in land use planning and decision-making processes - A European analysis. Chapter in the Book: Urban Agglomerations. Ed. InTech. pp. 87-106. https://doi.org/10.5772/intechopen.72191

[22] Castanho, R.A (2017). Sustainable urban planning in transboundary areas: Analysis of critical factors for territorial success. Doctoral Thesis University of Extremadura (UEx) Badajoz, Spain. Department of Vegetal Biology, Ecology and Earth Sciences.

[23] Koçak, E., Ulucak, R., Şentürk Ulucak, Z. (2020). The impact of tourism developments on $\mathrm{CO}_{2}$ emissions: An advanced panel data estimation. Tourism Management Perspectives, 33: 100611 https://doi.org/10.1016/j.tmp.2019.100611

[24] Castanho, R.A., Couto, G., Pimentel, P., Carvalho, C., Sousa, A. (2020). Territorial management and governance, regional public policies and their relationship with tourism. A case study of the Azores autonomous region. Sustainability, 12(15): 6059. https://doi.org/10.3390/su12156059

[25] UNWTO (United Nations World Tourism Organisation). (2008). International recommendations for tourism statistics. Madrid, Spain.

[26] Roy, S.C., Roy, M. (2015). Tourism in Bangladesh: Present status and future prospects. International Journal of Management Science and Business Administration, 1(8): 53-61. https://dx.doi.org/10.18775/ijmsba.18495664-5419.2014.18.1006

[27] van der Schyff, T. (2021). The development and testing of a measurement instrument for regional tourism competitiveness facilitating economic development. Doctoral Thesis. North-West University (NWU), South Africa.

[28] Karalkova, Y. (2016). Rural tourism destination competitiveness: Portugal vs. Belarus. DissertationMasters, Portugal: Polytechnic Institute of Bragança.

[29] Phillip, S., Hunter, C., Blackstock, K. (2010). A typology for defining agritourism. Tourism Management, 31(6): 754-758. https://doi.org/10.1016/j.tourman.2009.08.001

[30] Sonnino, R. (2004). For a 'Piece of Bread'? Interpreting sustainable development through agritourism in Southern Tuscany. Sociologia Ruralis, 44(3): 285-300. https://doi.org/10.1111/j.1467-9523.2004.00276.x

[31] Barbieri, C., Mshenga, P.M. (2008). The role of the firm and owner characteristics on the performance of agritourism farms. Sociologia Ruralis, 48(2): 166-183. https://doi.org/10.1111/j.1467-9523.2008.00450.x

[32] Gordon, J.E. (2018). Geoheritage, geotourism and the cultural landscape: Enhancing the visitor experience and promoting geoconservation. Geosciences, 8(4): 136-161. https://doi.org/10.3390/geosciences8040136

[33] Mitchell, J., Li, S. (2017). Autonomy found: Estimating the local benefit from tourism in SIDS-the case of Cape Verde. Journal of Policy Research in Tourism, Leisure and Events, 9(2): 182-200. https://doi.org/10.1080/19407963.2016.1261145

[34] Panfiluk, E. (2015). Impact of a tourist event of a regional range on the development of tourism. Social and Behavioural Sciences, 213: 1020-1027. https://doi.org/10.1016/j.sbspro.2015.11.520

[35] Smith, S.L. (2014). Tourism Analysis: A Handbook. 2nd ed. New York: Routledge.

[36] Andrades, L., Dimanche, F. (2017). Destination competitiveness and tourism development in Russia: Issues and challenges. Tourism Management, 62: 360376. https://doi.org/10.1016/j.tourman.2017.05.008

[37] Rizzi, P., Graziano, P. (2017). Regional perspective on global trends in tourism. Emerging Issues in Management, (3): 11-26.

[38] Castanho, R.A., Couto, G., Pimentel (2020). Principles of sustainable tourism and cultural management in rural and ultra-peripheral territories: Extracting guidelines for its application in the Azores archipelago. Cultural Management: Science and Education (CMSE). https://doi.org/10.30819/cmse.4-1.01

[39] Couto, G., Pimentel, P., Ponte, J.C., Gonçalves, P., Duarte, D., Arruda, A., Rodrigues, F. (2018). Azores: Investor's guide to sustainable tourism, Ponta Delgada: FLAD - Fundação Luso Americana para o Desenvolvimento. http://www.fundodemaneio.com/index.php.

[40] Silva, F., Almeida, M. (2013). Sustentabilidade do Turismo na natureza nos Açores - O caso do canyoning. Em M. Almeida, Turismo e Desporto na natureza (pp. 519), Estoril, Portugal: Asso- ciação de Desportos de Aventura Desnível. https://www.academia.edu/11936964/Sustentabilidade_ do_turismo_na_natureza_nos_Açores_O_caso_do_cany oning.

[41] Buckley, R. (2000). Neat trends: Current issues in nature, eco and adventure tourism. International Journal of Tourism Research, 2(6): 437-444. https://doi.org/10.1002/1522-

1970(200011/12)2:6<437::AID-JTR245>3.0.CO;2-\%23 
[42] Anderberg, M.R. (1973). Cluster Analysis for Applications. Academic Press, New York.

[43] Bacelar-Nicolau, H. (1987). On the Distribution Equivalence in Cluster Analysis. In: Devijver P.A., Kittler J. (eds) Pattern Recognition Theory and Applications. NATO ASI Series (Series F: Computer and Systems Sciences), vol 30. Springer, Berlin, Heidelberg. https://doi.org/10.1007/978-3-642-83069-3_7
[44] Lerman, I.C. (1981). Classification et Analyse Ordinale des Données; Dunod: Paris, France.

[45] Castanho, R.A., Loures, L., Cabezas, J., Fernández-Pozo, L. (2016). Identifying critical factors for success in Cross Border Cooperation (CBC) development projects. Habitat International, 72: 92-99. https://doi.org/10.1016/j.habitatint.2016.10.004 